\title{
'Whore-ocracy': Show Girls, the Beauty Trade-Off, and Mainstream Oppositional Discourse in Contemporary Italy ${ }^{1}$
}

\author{
DANIELLE HIPKINS
}

University of Exeter

Women on Italian television are objectified more frequently than on other European television networks. However, a moral panic in contemporary Italian culture about the figure of the 'velina', or television showgirl, perceived as dangerously akin to the scapegoated prostitute, has become shorthand for debates about Silvio Berlusconi, his media empire and political corruption. In this article I will begin by showing how a preoccupation with female performance and prostitution has in fact defined Italian culture since the Second World War. I will refer to the idea of 'the beauty myth' and how this has been used to keep women in a certain place in Italian society, showing how it has been further inflected in the Italian context by a beauty trade-off, namely the equation between female beauty, stupidity and sexual incontinence. I will then show how this history has informed the debate about the 'velina', 'velinismo', and women in public spaces to a point that seriously undermines criticism in the mainstream media, due to the terms used in the debate, the splitting of women, the beauty trade-off and problematic visual representations. I will suggest that in order to introduce some nuance into the 'velina' debate certain theoretical models require further development in the Italian context. These models stem from feminist media studies and the work of Rosalind Gill in particular, including postfeminist theory and subtler understandings of female subjectivity, pleasure and spectatorship.

KEYWORDS velina, prostitute, female beauty, Italian television, postfeminism

\footnotetext{
I thank family, friends and colleagues: Dominic, Simon, Karen, George, Kate Mitchell, Francesco Goglia, Fiona Handyside, Vicky Ball, and above all Ilaria Masenga and Catherine O'Rawe, who have given me useful information and many suggestions for this article. I also thank participants at workshops on prostitution, co-organized at the London Women's Library with Kate Taylor, March 20Io, and on Italian Political Cinema, November 2010 at Queen Mary College, London, for comments on earlier versions of this paper; and Alan O'Leary for engaging with my ideas on his blog. Finally, I am very grateful to the reviewers of this article, who made helpful suggestions for its improvement.
} 


\section{Introduction}

The antihero of the film Somewhere (Sofia Coppola, 20Io) is a jaded Hollywood actor, whose sex life consists of one night stands and regular visits from pole-dancing twins in his LA hotel room. One scene finds him receiving a prize on Italian television. Once handed the prize, he hesitates as young women in gold-sequined bikinis dance around him in what he clearly perceives as embarrassing proximity, particularly since his twelve year-old daughter is in the audience. It is no coincidence that Coppola chooses this particular setting to cause her hero to reflect upon his decline - the Italian television showgirl, or 'velina' as she is most commonly known, has become a shorthand for moral corruption and cultural decay, a shorthand which prominent thinkers and writers within Italy itself seem overly hasty to endorse.

At the most obvious level, however, 'velina' stands in for a host of television showgirls, whose appearance on Italian television dates back to the I950s. Their presence has become endemic in recent years, with an increasing emphasis on revealing their bodies in a stereotypically 'sexy' way: girls appear most often in hotpants or bikinis. Their diminutive labels generally reflect their status as 'grechine', decorative, but most often silent assistants, permitted the odd song, simple dance (stacchetto), or joke; the titles assigned to them range from the more traditional 'valletta' to the 'letterina', 'letteronza' and the 'prezzemolina'. The term 'velina' was coined to describe the two girls required to present items of news on the parodic television news show Striscia la notizia in I988, kneeling on top of the newsdesk, often wearing hotpants. The very name 'velina' carries political significance, since the term was a parodic allusion to the name given to the slips of paper dispatching instructions within the Fascist Ministry of Information, ironic now that she has become a by-word for right-wing cultural monopoly. Candida Morvillo recounts: 'Veline si diventa con poco. Non è richiesto saper cantare, ballare, recitare o parlare. Si guadagna tanto. Quindicimila euro al mese, includendo "serate" e telepromozione'. ${ }^{2}$ It is perhaps little wonder that increasing numbers of girls aspire to the role as a way to get rich quickly, although these numbers have been exaggerated in a widespread moral panic. The label gained particular notoriety when the competition to become a 'velina' was turned into a cult television show itself, Veline, the final of which attracted larger audiences than the final of Miss Italy. ${ }^{3}$ Two further terms have arisen from the 'velina': 'velinismo' and 'velinocrazia'. The terms are sometimes used interchangeably, but 'velinismo' tends to indicate the perceived triumph of this aspiration amongst young women, and 'velinocrazia' to describe the potential access to political power that has accompanied the role in recent years.

Alongside the label 'velinocrazia', 'mignottocrazia' — whoreocracy, has been coined by Berlusconi's opponents. There is evident slippage in the current discourse between the term 'velina' and prostitute — a link that has strong intellectual heritage. Pier Paolo Pasolini's critique of women on television is often cited to reinforce it:

2 Candida Morvillo, La repubblica delle veline: vita, vezzi e vizi delle ragazze della tivu dagli anni 50 ai giorni nostri (Milan: Rizzoli, 2003), p. 7.

3 Morvillo, p. 73. 
qui la donna è considerata a tutti gli effetti un essere inferiore: viene delegata a incarichi d'importanza minima, come per esempio informare dei programmi della giornata; ed è costretta a farlo in modo mostruoso, cioè con femminilità. Ne risulta una specie di puttana che lancia al pubblico sorrisi di imbarazzante complicità e fa laidi occhietti. ${ }^{4}$ (my emphasis)

Today the slippage between such female performers and the act of prostitution recurs in many depictions, from documentary film to fictional cameos: in one of the popular cinepanettone films, Natale a Rio (Neri Parenti, 2008), two Brazilian prostitutes are shown heading to Italy at the end of the film to take up jobs as 'veline'. One of the problems with the 'velina' issue is that, as Russell Campbell suggests with debates about prostitution, there is a tendency for the debate to freefall into patriarchal models of thought. ${ }^{5}$ In the case of the 'velina', some argue for the freedom of young women to choose how to use their bodies, and side with the kind of libertarian patriarchal thought that endorses the exploitation of economically disadvantaged women through the rhetoric of 'choice'. On the other hand, the argument that these young women do not know their own minds and need re-education is more than redolent of paternalistic, puritanical attitudes towards female sexuality. Thus the argument stagnates in dreary repetition, as most opposition collapses into these binary patterns of thought. Yet the most important question to ask about the 'velina' is: why does she matter so much? Why has the figure of the 'velina' come to incarnate all that is negative about Berlusconi's period of power? I will begin by showing that this tendency has its roots in the postwar cinematic equivalence of young, conventionally attractive, performing women, with the moralizing label of 'whore' (typically 'puttana' or 'mignotta' in Italian).

I will show how mainstream contemporary left-wing and feminist analysis in Italy has failed to shake off this equivalence, and often continues accidentally to reinforce it. ${ }^{6}$ The purpose of this article is not, however, to detract attention from sexism itself, which remains a fundamental and serious obstacle for women in Italy. Women on Italian television are objectified more frequently than on other European television networks. ${ }^{7}$ Critics of its use of women cite the CENSIS report of 2006 , which found that, with the exception of television drama, 'l'immagine più frequente dunque è quella della "donna di spettacolo". 8 This image is one-sided, and whilst it does not have to be objectifying per se, roles, costumes and camerawork often combine to make it so. As web activist Lorella Zanardo and others have explained, the particular and excessive objectification of women on Italian television has come around through

4 Quoted in La Repubblica, 5 June, 2009.

5 Russell Campbell, Marked Women: Prostitutes and Prostitution in the Cinema (Madison: University of Wisconsin Press, 2006).

${ }^{6}$ In focussing on mainstream media rhetoric, I have been able to make few references to grassroots feminist activism. The series of diverse responses to the situation from a wide range of third wave groups in Italy, particularly via the internet, nevertheless urgently demands recognition.

7 In the Censis report Donne e media nell'Europa of 2006, Italy and Greece feature as the countries 'resistant' to addressing change in the representation of women, quoted in Lorella Zanardo, Il corpo delle donne (Milan: Feltrinelli, 20I0), p. I40.

8 Quoted in Giovanna Campani, Veline nyokke e cilici (Bologna: Odoya, 2009), p. 92. 
the competition resulting from the deregulation of Italian television, and the expansion of Berlusconi's media empire. Private and state Italian television has failed to observe its own ethical codes of conduct, national and international law regarding the representation of women. ${ }^{9}$

In this article I would like to show how the tools of analysis currently employed to critique Italian culture could be strengthened in their attack on sexism by taking into account a new framework of analysis: postfeminism. At the moment, many critics regard Italy as undergoing the effects of a backlash: 'in a context marked by an anti-feminist backlash, many young women display a resistance to feminism, even while expressing feminist ideas' ${ }^{\text {Io }}$ The kind of disavowal described here is in fact more typically described in anglophone discourse as postfeminist. Postfeminism is a slippery term most often used to describe a stage beyond, but close to, the 'backlash' of the I990s, in which aspects of second wave feminism are reconciled with more traditional notions of femininity in contemporary popular culture. It is deeply enmeshed with the demands of neoliberal society to offer an apparent choice and associated with the proliferation of particular kinds of hyperfemininity, particularly an increasing 'sexualization'. Its theorization has made few inroads into Italian culture, and yet the emphasis in postfeminist theory, particularly in work by Rosalind Gill, on recognizing the complexity of the relationship between female subjectivity and popular culture could help to resolve the impasse described in this article.

\section{Postwar background}

\section{The emergence of the prostitute as scapegoat}

In Italy the Second World War enabled women to enter the public sphere in droves, taking over men's roles in their absence, and participating actively in the armed struggle for Italy's liberation. By way of recompense, they gained the vote in I946. What trace of this filtered onto the Italian screen? I have already argued elsewhere that many films depicting the occupation and liberation of Italy display women as prostitutes. ${ }^{\text {II }}$ Typically this has been read as a reflection of the real increase in the numbers of women turning to sex work, or as a symbolic denunciation of the Italian nation's prostituting itself to the Allied liberator. Equally one could argue that the prostitute created a reassuringly familiar narrative, rooted in the melodramatic tradition popular prior to the war. However, I have concluded that the main reason why women were depicted so pervasively as prostitutes in the context of film narratives of resistance, occupation, and liberation was to keep them trapped within an essentialist association with sex, and for them to act symbolically as scapegoats for Italy's

\footnotetext{
See Zanardo, pp. I05-I3.

ro Manuela Galletto, Chiara Lasala, Sveva Magaraggia, Chiara Martucci, Elisabetta Onori, and Charlotte Ross, 'Feminist Activism and Practice: Asserting Autonomy and Resisting Precarity' in Resisting the Tide: Cultures of Opposition under Berlusconi, 200I-6 (Continuum, 2009), ed. by Daniela Albertazzi, Clodagh Brook, Charlotte Ross, and Nina Rothenberg, pp. I90-203 (p. I94).

II See Danielle Hipkins, 'Were Sisters Doing It For Themselves?: The sister-prostitute and discredited masculinity in Italian cinema between 1940 and 1953' in War-Torn Tales: Representing Gender and World War II in Literature and Film, ed. by Danielle Hipkins and Gill Plain (Oxford: Peter Lang, 2007), pp. 8I-IO3.
} 
(silenced) role in the war, an inglorious story of conquered masculinities. A clear example lies in the Rome episode of Roberto Rossellini's film of I946, Paisà, in which the Italian girl, Francesca, explains to a GI that not all Italian women have turned to prostitution the way she has: 'There are lots of good, decent girls who are working, who have worked, who have found a way of defending themselves from hunger and poverty'. This vision of wartime prostitution as the morally weak girls' option was not limited to this episode. It was underlined in a radio speech the previous year by one of Italy's feminist writers, Sibilla Aleramo, whose moralistic inflection was reminiscent of Francesca's comment, as she paid tribute to those women who 'redimono la specie con esempi di bravura e di eroismo' whilst others 'trovano ancor

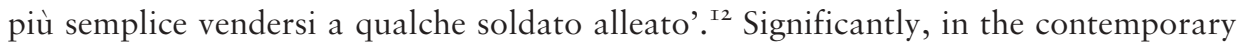
context one of the few commentators to refer to this long-term use of the prostitute figure in Italian culture is Pia Covre, a sex workers' rights activist, who asks: 'Di quanto siano state sempre necessarie le donne perdute per aumentare il valore delle donne per bene nella cultura patriarcale?'I3

\section{Bad girls: Growing female consumer power and activity in the public sphere}

In the late I940s female consumer power and activity in the public sphere slowly began to increase, if in the face of resistance. In cinema the influence of popular culture upon young women was depicted as corrupting through attacks on the 'fotoromanzi', weeklies for women recounting tales of romance through photographic comic strips. The first, and best known example of this kind of attack, is the story of Silvana, heroine of the left-wing movie Bitter Rice, I948, whom we see reading the most popular 'fotoromanzo' Grand Hôtel. The movie pulled in the crowds with its clever marketing of a new star, Silvana Mangano, promoted as the Italian Rita Hayworth, only to narrate her susceptibility to the 'fotoromanzo' and US-led consumer culture. Her beauty and her sexual incontinence were coupled with gullibility, if not stupidity, from which she could only redeem herself through suicide, thus fulfilling the need to destroy the female fetish figure, with a particularly Italian moralizing and left-wing political intent. Millicent Marcus has noted how in this film there is evidence of the longstanding tradition of using the female body to stand in for the vulnerable Italian body politic. ${ }^{\mathrm{I}}{ }^{4}$ However, the discourse is also directly and most obviously about female sexuality. In more conservative narratives, similarly vulnerable young girls, of a fundamentally virtuous nature, could be rescued from the hands of evil would-be white slave traffickers, who used the lure of the beauty contest, and the 'fotoromanzo' as a front for recruitment to prostitution, as in De Mitra's Verginità (I952). The double standards of a cinema that recruited almost all it of its stars, the so-called 'maggiorate fisiche', from beauty contests or 'fotoromanzi' (Sofia

\footnotetext{
${ }^{\text {I2 }}$ From a speech made by Sibilla Aleramo, 9 April 1945, quoted in Marta Boneschi, Senso: $i$ costumi sessuali degli italiani dal I880 a oggi (Milan: Mondadori, 2000), p. 233.

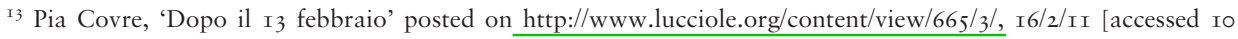
May 2OII].

${ }^{\text {I4 }}$ Millicent Marcus, 'The Italian Body Politic is a Woman: Feminized National Identity in Post-war Italian Film' in Sparks and Seeds: Medieval Literature and its Afterlife - Essays in Honour of John Freccero, ed. by D. E. Stewart and A. Cornish (Turnhout, Belgium: Brepols, 2000), pp. 329-47.
} 
Loren being the best-known example) appear striking, but they add up to a general lack of respect for female performers. In many film narratives of the period performing women of all kinds fell under the shadow of prostitution: a tendency at play in culture more broadly, as Kirsten Pullen has observed. ${ }^{\text {I5 }}$

Lucia Cardone has shown how the magazine Noidonne, the women's magazine initially associated with the Italian Communist Party, founded in 1944, and dedicated to recruiting women to the left, ended up in much the same conundrum in the I95os. Whilst distancing itself from the 'fotoromanzo', the magazine used popular cinema and beauty culture to attract a readership. Whilst selling the magazines with stories and images of cinema and stardom, it went to great lengths to create morality tales about the horrors that would befall 'normal' women who attempted to become stars, just as more conservative women's magazines of the period did. $^{16}$ In relation to Cardone's study of this particular magazine, which could be regarded as a potentially proto-feminist model, it is useful to observe how the emergence of a particular strand of intervention, mingling the moralizing left-wing paternalistic model with concern about the experience of ordinary women, tends to 'other' the female star, and any young aspiring starlet. This is a trend, we will see later, which survives second-wave feminism of the I970s, to emerge in the present day in a similarly problematic fashion.

\section{The beauty trade-off}

In his book Bellissima: Feminine Beauty and the Idea of Italy, Stephen Gundle writes that 'the very long-standing high cultural tradition of preoccupation' with feminine beauty is 'unique to the peninsula'. ${ }^{17}$ He goes on to add that 'the emphasis on beauty both took something from women (in so far as its deployment could be - and was - used against claims for legal equality and access to education) and gave them something, namely visibility and a central place in the construction of the national community'. ${ }^{18}$ What the beauty cult took away from women remains in brackets for Gundle. However, Umberto Eco reminds us of the darker connotations of feminine beauty, when he writes that:

Tertulliano [...] ricorda come 'secondo le Scritture gli adescamenti della bellezza fan sempre tutt'uno con la prostituzione del corpo'. A parte la condanna morale (e l'evidente polemica con la licenza del mondo pagano), appare evidente l'insinuazione che la donna si trucchi con impiastri e altri artifici per mascherare i suoi difetti fisici, nella vanitosa illusione di rendersi piacente al marito, o peggio, agli estranei. ${ }^{19}$

In a more contemporary key, Naomi Wolf's polemic of I990, The Beauty Myth anticipated how central to neo-liberal capitalism the preservation of a youthful and beautiful appearance was to become for women, and how damaging that was for

\footnotetext{
${ }^{15}$ Kirsten Pullen, Actresses and Whores: On Stage and in Society (Cambridge: Cambridge University Press, 2005).

${ }^{16}$ Lucia Cardone, 'Noi donne' e il cinema: Dalle illusioni a Zavattini (I944-54) (Pisa: Edizioni ETS, 2009), pp. $87-88$.

${ }^{17}$ Stephen Gundle, Bellissima: Feminine Beauty and the Idea of Italy (Yale University Press, 2007), p. xix.

${ }^{18}$ Gundle, p. xxv.

I9 Umberto Eco, Storia della bruttezza (Turin: Bompiani, 2007), p. I59.
} 
them. Wolf argued that the beauty myth was a form of penalty exacted upon women for their increasing participation in the public sphere. ${ }^{20}$ Although polemical, her argument has relevance to the Italian case, for the ferocity with which the cult of beauty was promoted in the postwar period did shadow women's increasing public participation. Indeed the popular beauty contest, arguably, became a distorted parody of democracy for women. Wolf claimed that women internalize the idea of being punished for their public role, and participate in the Beauty Myth through dieting, eating disorders, and financial indenture to the beauty industry. In the Italian context, the double bind of beauty was taken several degrees further, layered upon old prejudices described by Eco, to form a sort of twisted beauty trade-off: beauty made one desirable, and one should aspire to it, but if one possessed it (or even worse, aspired to possess it), one automatically became bad, stupid, or a whore: possibly all three. Here we can see, with Maggie O'Neill, that " "the whore stigma” [...] is transferable to all women, but particularly to those who transgress the rules and norms that "control" women morally and socially'. ${ }^{2 \mathrm{I}}$ In gaining power through their beauty, women break those rules and norms, and must pay a price.

We can see traces of how the many women, who fall outside the idealized and vilified model of beauty, may have manipulated the beauty trade-off to survive in the film-making practices of a female star in the I950s. Franca Valeri was one of the few female stars of the period to make a name by manipulating her fast-talking, witty persona and lack of a 'maggiorata' physique to comic ends. In her own words: 'Quasi sempre ero messa in contrapposizione con una molto bella [...] C'era sempre una "bona", una bella che sposava il ragazzo, e io che facevo l'antagonista comica'. ${ }^{22}$ There is no doubt that in making 'other women' and their dilemmas at least visible in Italian cinema she served an important role that deserves further investigation. For the purposes of this piece, however, it is significant that her I955 film Piccola Posta (dir. Steno), uses the young and gullible beauty as a figure of fun. A mocking scene from Piccola Posta shows the girl measuring her vital statistics, as she reads the ideal measurements from a woman's magazine. What we see here is an example of how the denigration of women is internalized by those very women who want to distance themselves from it. In this process, women who are critical of the 'beauty myth' focus upon the women seen to embody it, and not the system itself, in order to articulate their dissatisfaction. In this way the critique becomes divisive. Franca Valeri would not be the last critic of the beauty cult to attack it via its very embodiment. ${ }^{23}$

\section{Dirty pretty things: recent debates about showgirls}

The function of the aspiring 'velina' as a substitute for the morally endangered girl of the I950s, caught somewhere between the aspiring starlet and the prostitute, has

\footnotetext{
${ }^{20}$ Naomi Wolf, The Beauty Myth: How images of beauty are used against women (London: Vintage, I990), p. II.

${ }^{21}$ Maggie O’Neill, Prostitution and Feminism: Towards a Politics of Feeling (Cambridge: Polity Press, 2000), p. 186.

22 'Il segno di Franca: Intervista con una signora molto snob', in Franca Valeri: Una signora molto snob, ed. by Emanuela Martini (Turin: Lindau, 2000), p. 68.

23 The popular stand-up comedian, Sabina Guzzanti, recently mobilized a similar attack on the 'velina' aspiration in her show. See an extract at http://www.youtube.com/watch?v=94u3wO-yR6Y [accessed I2 June $20 \mathrm{II}$ ].
} 
developed since her first appearances on Italian television in the I980s, and in that context the 'velina' has gained increasing significance in debates about feminism. In 1994 left-wing female students protested on International Women's Day against Ambra Angiolini, one of the new adolescent dancers to emerge on the television programme Non è la Rai, who had expressed public support for Berlusconi. An incident that recurs in recent sensationalism about the 'velina' as cipher for the 'end of feminism' is the notorious 'donna plexiglas' of 2000. Twenty-two year old 'valletta' Flavia Vento appeared in a glass cage, under a table, from which she was allowed out to make the odd joke and sing out of tune, as a feature of the comic television programme, Libero. In the furore that ensued, the feminist anthropologist, Ida Magli declared it 'l'ultima frontiera dell'annullamento del femminismo'. ${ }^{24}$

Responses to Berlusconi's private parties, to which he invites showgirls from his television channels, as well as escorts, and reports of his attempts to put some of them into parliament return us once again to the 'othering' of young, beautiful women. Part of a country that has rarely questioned its dependency on the 'beautiful women' cliché, suddenly finds itself in moral outrage that its parliament has turned into a 'beauty contest'. ${ }^{25}$ It is a question of female bodies transgressing boundaries and connoting pollution. ${ }^{26}$ There can be no doubt that the beauty contest culture still underpins the showgirl phenomenon, ${ }^{27}$ but beauty contests are, all of a sudden, morally problematic when they also involve political power for women. That the beauty contest culture has potentially been oppressing Italian women for the past fifty years has never been widely recognized: now that it involves political power for women, its perversion of democracy is finally deemed important.

I will not examine the Berlusconi scandals here; their tawdry range has been well documented by the international media, if not the Italian press. ${ }^{28}$ The scorn heaped upon the young women in show business involved in the scandals does interest me, however, since such scorn often appears to imply that it is they who are at fault, and displaces preoccupation with the real problem: widespread accusations of political corruption relating to Italy's Prime Minister. Of course, as has been highlighted, the Italian press's reluctance to reveal the full extent of Berlusconi's corruption leads towards a very public scapegoating of any women who criticize him, not least of all his ex-wife, Veronia Lario. ${ }^{29}$ Unfortunately very similar discursive framing is used by what I shall term 'oppositional discourse' to the 'velina'. The 'opposition' is best explained by Daniele Albertazzi and Nina Rothenburg: 'opposition to Berlusconi's political and cultural hegemony has come mainly from minoritarian sections of the

${ }^{24}$ Quoted in Morvillo, p. 65.

25 Senator Paolo Guzzanti in interview in the documentary Le dame e il cavaliere, (Franco Fracassi, 20Io).

${ }^{26}$ For discussion of the prostitute as a pollution symbol that draws upon the work of Mary Douglas: 'Pollution symbols [...] define what is and is not permissible in a society at any given time', see Melanie Bell-Williams, 'Shop-soiled Women: The Figure of the Prostitute in Late I950s British Film Culture', Journal of British Cinema and Television, 3:2 (2006), pp. 266-83, (p. 272).

27 Morvillo, p. 233.

${ }_{28}$ Peter Gomez, Marco Lillo and Marco Travaglio, Papi: uno scandalo politico (Milan: Chiarelettere, 2009), p. 282 .

29 Infamously, when Lario criticized her husband publically in 2009, the newspaper close to Berlusconi, Libero, 'sbatte in prima pagina tre vecchie fotografie in bianconero della giovane attrice Veronica Lario a seno nudo, raccattate chissà dove e chissà da chi, e la chiama "velina ingrata": Gomez, et al., p. I5I. 
population, generally from groups the historian Paul Ginsborg referred to as "the reflexive middle classes", ${ }^{30}$ Where opposition to media representation and to Berlusconi's treatment of women in everyday practice is concerned, this group includes self-appointed representatives of what has been identified as 'a new tradition of feminist mass protest' arising since the G8 meeting in Genova 200I: journalists and academic, popular, and party political feminists with a high profile on the internet, mainstream newspapers, or in popular feminist publications. ${ }^{3 \mathrm{I}}$ This opposition uses new media and mainstream traditional media to make its points, alongside more traditional left-wing journalists and documentary makers. I will examine some of the key features of this debate: language referring to prostitution, the splitting of women, the beauty trade-off, and problematic visual representations, all of which resonate strongly with the historical background described above. A final important aspect to the 'velina' debate is the popular truism that all young women aspire to be 'veline', which barely masks an anxiety about female spectatorship that has roots in the I950s and earlier, and to which I will return in my conclusion. ${ }^{32}$

\section{'Mignottocrazia' and 'Velinocrazia' - performers, politicians and prostitutes}

The recent coinage of the term 'mignottocrazia' arose with reference to a specific woman, making its political 'othering' of women, and subsequent popularity, all the more treacherous. Paolo Guzzanti, a right-wing senator who has since resigned from Berlusconi's party, Forza Italia, was referring to the rise of Mara Carfagna, law graduate, former beauty show contestant, occasional topless model and showgirl (ex-valletta from Rete 4's 'Domenica del villaggio'), turned politician, who was appointed Minister for Equal Opportunities in May 2008. Yet the question of sex work does not come into Mara Carfagna's history, so already we can see how this particular slippage occurs as a reflex. The association was further compounded in autumn 2008 by Mara Carfagna's heavy-handed attempts to introduce a law involving new penalties for street prostitutes and their clients at the very moment when the details of the Prime Minister's own use of prostitutes emerged. ${ }^{33}$ Carfagna's clumsy moralizing gloss on the law added insult to injury: 'come donna mi fa orrore questo fenomeno, non comprendo chi vende il proprio corpo per trarne profitto'. This triggered a protest from Carla Corso, a founder of the committee for prostitutes' rights, who observed that 'La signora ha usato il suo corpo per arrivare dove è arrivata. Basta aprire l'internet per vedere le sue grazie'. ${ }^{34}$ Corso's coy terminology makes a valid point about Carfagna’s hypocrisy, echoing Rolland Munro’s suggestion that 'it

$3^{\circ}$ Daniele Albertazzi and Nina Rothenburg, introduction to Resisting the Tide: Cultures of Opposition under Berlusconi, 200I-6, pp. I-I6 (p. Iо).

${ }^{31}$ Galletto, et al., p. I97.

${ }^{32}$ In forthcoming work I explore how popular narrative film engages in more complex discourses about the figure of the 'velina' and her female spectators.

33 "Un ddl dal titolo "Misure contro la prostituzione" che introduce il reato di esercizio della prostituzione, sia pur limitandolo ai luoghi pubblici o aperti al pubblico, e fissa l'arresto (da cinque a quindici giorni) e pesanti multe (da 200 a 3 mila euro) per le prostitute e per il cliente', Caterina Soffici, Ma le donne no: come si vive nel paese più maschilista d'Europa (Milan: Feltrinelli, 20I0), p. 85.

34 Soffici, p. 86. 
is the prostitute [...] who helps us deny our own everyday commodification of each other'. ${ }^{35}$ Far from being read in this key, however, a series of problematic comments from Carfagna unleashed a flood of misogyny, partly in the form of internet montage sequences juxtaposing calendar shots of Carfagna with her statements: on the internet such montages are commonplace, but their uncritical screening at academic conferences speaks to the great confusion about the representation of women on the part of an intellectual left-wing minority.

Slippage in terms becomes more acute when we consider that alongside the term 'mignottocrazia' there emerged the term 'velinocrazia' or 'velinismo', ${ }^{36}$ drawing strength from Berlusconi's largely unsuccessful attempt in 2009 to put forward as candidates for the European parliament women originating in show business with little political training. A cloud of obscurity (recorded telephone conversations reported second-hand and then 'archived' by judges under sudden new laws, and conflicting accounts) has aggravated confusion about the women attending the private parties at the prime minister's homes Palazzo Grazioli and Villa Certosa events organized to flatter Berlusconi's ego by providing him with many young women to flirt and to have, allegedly, paid sex with. This has triggered a preoccupation with finding out more, which has turned upon dividing those women into good women who resisted and bad women who did not. ${ }^{37}$ This kind of moralizing sensationalism has been evident in the reporting of the recent underage prostitution scandal known as Rubygate, in the left-wing La Repubblica, as elsewhere. ${ }^{38}$ There is no doubt here that left-wing newspapers also recycle the association between 'velina', sex scandals, and increased readership that journalists involved in more popular press, such as Morvillo (she is currently director of the gossip magazine Novella 2000) are more open about: in her book Morvillo confesses that the newsworthiness of the 'veline' is largely constituted by their involvement in any sex scandals. ${ }^{39}$ The result is that many of the showgirls who attended the parties have become even more closely entangled with the term 'escort'. ${ }^{\circ}$ The words of a young legal prosecutor who attended some of the parties at Palazzo Grazioli reflect a popular view of the escort: 'Le prime volte c'erano deputate, attrici, manager. Insomma persone con una professione. Adesso sono soprattutto escort e la mosca bianca sei tu che lavori' (my emphasis). ${ }^{4 \mathrm{I}}$ Here we get to the crux of the matter: sex work is not regarded as work, taking us back to Sibilla Aleramo's words separating good working girls from the rest.

35 Quoted in O’Neill, p. I45.

${ }^{36}$ See Gad Lerner's blog entry of 29 April 2009: “"Velinismo” politico e mignottocrazia', http://www.gadlerner. it/2009/04/29/velinismo-politico-e-mignottocrazia.html [accessed 9 May 20II].

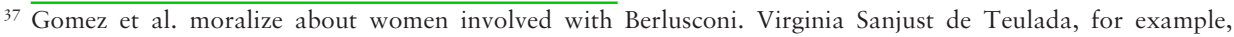
with whom Berlusconi had an affair in 2003, is represented as a good girl, rejecting his offers of money and represented as really loving the man, p. 3I.

$3^{8}$ See the article in La Repubblica reporting on the taped phone conversations surrounding Rubygate, which includes moralizing commentary and a photograph of each girl, Piero Colaprico and Emilio Randacio, 'Le confessioni delle ragazze di Arcore', I8 March 20II, pp. 20-2I, following from the front page.

39 Morvillo, p. 229.

$4^{\circ}$ This term in itself caused controversy, viewed as a foreign import word employed by the Berlusconi camp to cushion the impact of the word 'prostituta'. See Gomez et al. who discuss TGI in which 'cambiano nome alle cose per nasconderle meglio (“escort” invece di prostitute [...] "utilizzatore finale” invece di clienti)', p. I3.

${ }^{4}$ I Interviewed for L'Unità, 23 april 2009 in 'Il segno della farfalla' by Concita De Gregorio, quoted in Gomez et al., p. II6. 


\section{'Other women' versus 'real women'}

The result of this division is that a mass march, organized on $I 3^{\text {th }}$ February $20 \mathrm{II}$ by the women's protest group Se non ora quando, to protest against the prime minister's treatment of women in a supposedly inclusive fashion, was rejected or greeted ambivalently by those who saw it as protest against other women of all kinds..$^{42}$ If we examine more closely the language associated with some of these recent calls for action such a response is hardly surprising. Popular activist Lorella Zanardo has stated that her critique of Italian television is not intended as a moral condemnation of the 'veline' themselves. ${ }^{43}$ Indeed she observed with horror how in response to her own popular internet-based documentary about the objectification of women's bodies on Italian television, Il corpo delle donne, launched in 2009, women turned upon one another. ${ }^{44}$ However the discourse that insistently divides women into separate categories occasionally includes Zanardo's own. Zanardo describes how 'sul blog de Il Corpo delle Donne abbiamo inaugurato una rubrica, Metterci la faccia - volti alternativi ai "non volti" televisivi e pubblicitari' (my italics). ${ }^{45}$ There is a preoccupation with the female face in many protests that rests on the fact that most women who appear on Italian television represent only young, attractive, slim women, some of whom have had plastic surgery. In the words of Caterina Soffici: 'La televisione italiana mostra solo ragazze belle e giovani, o donne rifatte, i corpi di donne reali sono occultati, rimossi e sostituiti con altri materiali, di norma il silicone e il botulino' (my italics). ${ }^{46}$ With their emphasis on 'volti alternativi' and 'donne reali' Zanardo and Soffici unconsciously imply that 'veline' or cosmetically operated women do not have real faces, or bodies of their own.

This moralizing attitude appears designed to alienate a whole swathe of women who conform to certain bodily regimes as part of their gender performance. The moralizing tones taken towards cosmetic surgery witnessed above extend to the condemnation of excessive make-up. As for Tertullian, the moral index of beauty can signify greater or lesser honesty according to its degree of artifice. This manifests itself at its most virulent in the video, fronted by the actress Angela Finocchiaro, that called for participation in the march on $\mathrm{I} 3^{\text {th }}$ February. In this video, Finocchiaro asked women to join the march, ending: 'e mostriamo nude, le nostre facce', as if any poor soul who accidentally slipped into her morning ritual of foundation and mascara might be summarily ejected. ${ }^{47}$ A comment from established journalist for $\mathrm{La}$ Repubblica, Natalia Aspesi, hints at a form of incomprehension on the part of older generations of women with the power to speak (and judge) when she discusses the case of Noemi Letizia, the Neapolitan girl who called Berlusconi 'Papi' and became the centre of a scandal when he attended her eighteenth birthday party in April 2009: 'la diciottenne Noemi che con la sua grazia gentile è un clone indistinguibile delle sue

\footnotetext{
$4^{2}$ See Pia Covre, cited above. See also popular novelist, Melissa P. in interview with Elly Schlein, http://www. stilefemminile.it/melissa-p-litalia-non-e-un-paese-per-donne/, posted on 7/2/II [accessed Io Mat 2OII].

43 Zanardo, p. I24.

${ }_{44}$ Zanardo, p. I25.

45 Zanardo, p. 83.

${ }^{46}$ Soffici, p. Io8.

${ }^{47}$ http://www.youtube.com/watch?v=zma-HI-yF3w [accessed II/05/II].
} 
coetanee, tutte con capelli biondi e lisci, corpicino stretto, sorriso fisso, pazze per lo shopping, meta Il Grande Fratello, per lei oltre a papi, si capisce'. ${ }^{8}$ This disdain for young women's practices around the body, taste and consumption, and this rhetoric of 'all the same', rings a familiar bell if we look back to the I950s and anxieties about the 'fotoromanzo'. Its relation to a panic about consumption, and its displacement onto the prostitute, "simply the "end stop" in discourses on "good" and "honest" women', ${ }^{49}$ is evident in a recent article by Concita De Gregorio, director of L'Unità newspaper, entitled precisely: 'Le altre donne', which speaks to this discussion on many levels:

Osservo le ragazze che entrano ed escono dalla Questura, in questi giorni: portano borse firmate grandi come valige, scarpe di Manolo Blanick [sic.], occhiali giganti che costano quanto un appartamento in affitto. È per avere questo che passano le notti travestite da infermiere a fingere di fare iniezioni e farsele fare da un vecchio miliardario ossessionato dalla sua virilità. [...] Ancora una volta, il baratro non è politico: è culturale. È l'assenza di istruzione, di cultura, di consapevolezza, di dignità..$^{\circ}$

Given the frequent association of prostitution with working class women, ${ }^{5 \mathrm{I}}$ it is not difficult to see similar issues at stake here. Is the anxiety about 'veline' also an anxiety about working class femininity (and the 'feminized' body politic, as Marcus would suggest)? About the 'difference' of a whole class (of women) in Italy, who must be made to conform to acceptably middle class tastes and aspirations? In his blog on the cinepanettone Alan O'Leary astutely contests that this popular film genre (despised by the cultural elite) and the 'velina' are both markers of supposedly low levels of taste for a certain contingency: 'they function in the prose of the appalled as the mutually reinforcing anti-pillars of the presumed depths to which Italian culture has fallen'. ${ }^{2}$ De Gregorio's article was accompanied by an appeal for signatures with the cry 'Ora basta', but alongside many supporting signatures, it did trigger a series of criticisms, particularly from individuals, feminist groups, ${ }^{53}$ and prostitutes' rights organizations. ${ }^{54}$

\section{The beauty trade-off: 'L'ocaggine' and the circularity of the 'Bellissima' paradigm}

One of the aspects of the 'velina' archetype under attack from the opposition: 'la presunta ocaggine come attrattiva', in Zanardo's words, ${ }^{55}$ is another feature of the

$4^{8}$ Natalia Aspesi, 'Veronica e le donne al tempo del Cavaliere', La Repubblica, I3 May 2009.

49 O’Neill, p. I86.

$5 \circ$ Concita De Gregorio, 'Le altre donne', appeared on the website of L'Unità, I9 January 20 II.

${ }^{51}$ O'Neill, p. I34.

52 See Alan O'Leary, 'Scapegoating the velina: the left and the body of the woman', at http://holidaypictures. tumblr.com, posted April 20II [accessed Io May 20II].

53 In their response to De Gregorio on L'Unità's website, feminist group figliefemministe express the slogan: 'Siamo puttane, siamo antirazziste, siamo antifasciste!' http:/www.unita.it/donne/dove-siete-donne-diciamoora-basta-firma-br-oltre-37mila-firme-perina-costa-dante-forte-I.266963, posted on 5 February $201 \mathrm{I}$, accessed Io May 20 II.

${ }^{54}$ A main site for the latter (www.lucciole.org) provides a link to a feminist blog, which expresses a growing resistance to this othering process http:/quaderniviola.blogspot.com/20II/oI/considerazioni-sul-rubygate.html (Lidia Cirillo, 'Alcuni considerazioni sul Rubygate') [accessed Io May 20II].

55 Zanardo, p. 28. 
beauty trade-off. Morvillo dedicates a chapter of her book to the cultivation of 'l'ocaggine', or 'bimboness' in the 'velina', but it is not the only facet, she is at pains to point out, citing the number of academically well-qualified 'veline' ${ }^{56}$ The extreme consequences of making women feel stupid can be traced in Morvillo's account of why sexual exploitation has become endemic within television; she comments: 'Alla fine, queste sventurate si sentono stupide e ingannate, così se ne stanno zitte e il gioco continua, in Rai e fuori'. ${ }^{57}$ This reluctance to talk is one of the most serious consequences of the beauty trade-off. Far from protecting girls and women from exploitation, depicting them as stupid makes them more vulnerable to it, because they feel unable to denounce exploitation for fear of appearing to be the 'oche' they are expected to be. Yet, often the attacks on the exploitation of women from the opposition are undermined by their own recycling of the same system of signification. This was never more so than in the case of Noemi Letizia, the eighteen year old Neapolitan mentioned above. One of many examples of the beauty trade-off in responses to her was La repubblica newspaper's intimation that Letizia's appearance at the Venice film festival was marred by a missed subjunctive. ${ }^{5}$ Here discourses of class, regionalism, and gender intersect to use the beauty trade-off to maximum effect.

A further intractable problem with the criticism of the debate from the opposition is a lack of vocabulary with which to talk about female bodies and appearance: the word 'bella' has a cheap but irresistible currency in the Italian language. In the book by left-wing L'Espresso journalist, Peter Gomez, and his colleagues, the writers struggle because they fight like with like in the discursive framing of their subjects. Evelina Manna, involved in the Raifiction scandal, ${ }^{59}$ is described as 'una bellissima ragazza che si avvicina alla quarantina', and as 'questa ragazza dal fisico mozzafiato'. ${ }^{60}$ One understands the need for descriptive vocabulary, but theirs hardly challenges the beauty myth, and their confusion of girls and women is 'quintessentially postfeminist'. ${ }^{6}$ Furthermore Gomez et al. attack the vocabulary of Belusconi's lawyer, Niccolo Ghedini, who declared that "'Berlusconi ha grande rispetto per il mondo femminile e non ha bisogno di pagare 2000 euro per una ragazza: potrebbe averne grandi quantitativi gratis". Notare la soavità dell'espressione "grandi quantitativi gratis". Come se il corpo femminile fosse una merce da scaricare in appositi container'. ${ }^{62}$ Yet they struggle to make any distinction in quality between his vocabulary and theirs: 'Le foto scattate da Zappadu a Villa Certosa [...] immortalano adunate oceaniche di corpi femminili, o "grandi quantitativi di donne" per dirla con Ghedini',

\footnotetext{
${ }^{56}$ Morvillo, p. 34 .

57 Morvillo, p. 230.

${ }^{8}$ Claudia Morgoglione, 'Ressa per Noemi Letizia al lido con mamma e papà', La Repubblica, ro/o9/o9, http:// www.repubblica.it/2009/o9/sezioni/spettacoli_e_cultura/cinema/venezia/noemi-lido/noemi-lido/noemi-lido.html [accessed 29 June 20II].

59 The Raifiction scandal revolved around telephone conversations, taped in 2007, in which Berlusconi pestered the head of drama for Italian state television, Agostino Saccà, to find jobs for his female friends.

${ }^{60}$ Gomez et al., p. 68.

${ }^{61}$ Diane Negra, What a Girl Wants: Fantasizing the Reclamation of Self in Postfeminism (London: Routledge, 2009), p. I2.

${ }^{62}$ Gomez et al., p. 28I.
} 
adding 'Solo con un lavoro di mosaico i giornalisti e i pm che interrogano le ragazze [...] riescono ad associare quel groviglio di volti e di glutei ad altrettanti nomi e cognomi' ${ }^{63}$ (my italics).

\section{Problematic visual representations}

The attempt to translate the concept of a 'groviglio di volti e di glutei' into the visual constitutes one of the principal problems with some documentary responses to 'velinismo', namely Il corpo delle donne (Zanardo, 2009) and Videocracy - Basta apparire (Gandini, 2009). Fêted for its incisive criticism of the Italian government, which led to a refusal on the part of Rai and Mediaset to screen its trailers, Gandini's film does not give any voice to an undifferentiated mass of writhing bodies taking part in a 'veline' audition. Through repetition, this scene becomes an iconic image in tune with the dominant discourse on the topic, in which the youthful female mass is carnal anonymity, inviting or politically dangerous, depending on one's perspective. In Soffici's words: 'l'immagine della donna veicolata dalla televisione è un susseguirsi di corpi, gambe e seni scoperti'. ${ }^{64}$ This language shows the influence of Lorella Zanardo's internet-launched documentary, Il corpo delle donne, a shocking and sensationalist montage sequence accompanied by her own critical voice-over of the ways in which bodies of women have been objectified on Italian television. It includes a particularly disturbing sequence in which a woman's behind hangs from the ceiling amongst a selection of hams, and the contestant attempts to 'hook' it, as in a butcher's shop. A rallying cry to women not to let themselves be manipulated into objectification, this video drew considerable support and attention, particularly after its presentation on Gad Lerner's television programme L'infedele, ${ }^{65}$ and the documentary has now been seen by three and a half million people.

In the documentary, Zanardo presents her important analysis of women in television with little acknowledgement of twenty years of feminist critique, although in her written text to accompany the video this is more in evidence, and she harangues women for their failure to react to Italian television. Although Zanardo's emphasis is on promoting a vital media literacy, 'nuovi occhi per la televisione', ${ }^{66}$ in the documentary her montage of objectifying images of women is problematic as a form of critique. It perpetuates a visual economy of objectification, and the fragments of female humiliation that she uses appear to attribute stupidity to the female objects on display, although that is not her intent. Although clearly driven by lack of budget and a desire to create a polemic, Zanardo's method nonetheless activates a traditional form of critique, such as that employed by Franca Valeri, which focuses upon the embodiment of female oppression, rather than its causes. It is also close to the 'content analysis' approach common in the I970s: as Gill points out, such an 'approach does not distinguish between levels of meaning, and, in fact, only ever

\footnotetext{
${ }^{63}$ Gomez et al., pp. 249-50.

${ }^{6}$ Soffici, p. Io8.

${ }^{65}$ La7, 4 May 2009.

${ }^{66}$ She has promoted the video in schools and bookshops around the country; also see 'Lezioni di televisione' at http://www.ilcorpodelledonne.net/?page_id=I882, and her book, pp. 58-80.
} 
addresses the manifest content of representations' ${ }^{67}$ Zanardo herself is aware of this, since in a blog post subsequently published in her book, she presents a more interesting reading of the different styles of 'veline': 'Flavia Vento sotto il tavolo ci provocava indignazione anche per il suo sguardo smarrito e sottomesso [...] Belen invece conosce le potenzialità del suo fascino e ci gioca con leggerezza, forte del potere del suo corpo sul pubblico maschile e femminile'. ${ }^{68}$ Like much postfeminist analysis, this approach emphasizes the need for nuance in defining the meaning of the sexualized image. ${ }^{69}$ 'Che sia necessario fare un distinguo tra corpi sottomessi e umiliati e corpi esibiti in modo attivo'70 is something Zanardo should foreground more frequently, since Morvillo's account of the 'velina' reveals the phenomenon to be one rich in potential meaning, deserving further investigation. Such an opportunity was missed by Zanardo's film, which may account for the number of responses that attack the performing women themselves. In this respect what Gill describes as a move from objectification to 'subjectification' would also be helpful:

From sex object to desiring sexual subject: this shift is crucial to understanding the postfeminist sensibility. It represents a modernization of femininity to include what Hilary Radner has called a new 'technology of sexiness' in which sexual knowledge and sexual practice are central. [...] I would argue that it represents a higher or deeper form of exploitation than objectification - one in which the objectifying male gaze is internalized to form a new disciplinary regime. ${ }^{7 \mathrm{I}}$

This reading of Gill's is close to Zanardo's own reading of Italian television culture and its 'estetica di uno stripclub'. Indeed Gill seeks, like Zanardo, to make the operations of a 'new sexism' speakable once again, but Gill is also able to recognize what is 'new' about that sexism, and implies that distinguishing between 'corpi sottomessi e umiliati e corpi esibiti in modo attivo' is not as straightforward as Zanardo might imply.

The vulnerabilities of Zanardo's original critique have come to the fore recently with the creation of an anti-Zanardo spoof courtesy of the Mediaset-owned (and therefore Berlusconi-controlled) television critical news programme Striscia la notizia, one of the programmes condemned by Zanardo for its use of women as decorative objects. The programme created 'Il corpo delle donne 2: La mercificazione della donna nella stampa progressista', ${ }^{72}$ parodying Zanardo's critical voiceover, and setting it instead to images from the left-wing press, pointing out that the objectification of female bodies spreads across the political spectrum. By failing to connect with feminist media studies critique, Gandini, and to a certain extent Zanardo, have made the mistake of letting the 'velina' debate and the objectification of women appear to be tied up solely with 'Berlusconismo'. Whilst recycling images of fragmented, apparently stupid female bodies has actually exposed Zanardo to criticism from the right,

\footnotetext{
${ }^{67}$ Rosalind Gill, Gender and the Media (Cambridge: Polity Press, 2006), p. 44.

${ }^{68}$ Zanardo, p. I40.

${ }^{69}$ Rosalind Gill, 'Sexism Reloaded, or, it's time to get angry again' in Feminist Media Studies, II:I (2OII), pp. 6I-7I (p. 65).

70 Zanardo, p. I42.

${ }^{71}$ Gill, Gender and the Media, p. 258.

${ }^{72}$ http://www.striscialanotizia.mediaset.it/video/videoextra.shtml?I276I [accessed Io May 20II].
} 
it is important to observe that this attack on her film came two years after its release, in the wake of the Berlusconi sex scandals, suggesting that she has indeed been the object of a very pointed political counterattack, which in itself also pays tribute to the impact of her film.

Those documentaries that give any space to female protagonists to speak are inevitably more successful in distancing themselves from traditional forms of representation. The film Le dame e il cavaliere (Franco Fracassi, 20Io) gives adequate screen time to Patrizia D'Addario and Barbara Montereale (two women attending Palazzo Grazioli parties) to present their stories in straightforward and lengthy interviews, one reason why the film encountered a serious problem with distribution, outlawed as it was by the Legge Bavaglio, protecting the Prime Minister's privacy, in June 20IO. The screen time given to the women to speak is refreshing, at least until Montereale's interview is intercut with images of her as beauty queen in a swimming costume. A more innovative approach is Vittorio Moroni's film dedicated to women and love Eva e Adamo (2009), which features three women in 'extreme' romantic situations. One of them is 20 year-old Deborah, who works as a live stripper on a phone-in for a small private television channel. The drama of the documentary unfolds as her boyfriend finds out what she does, and she attempts to break into the porn film industry, whilst bringing up her newborn baby. The director attempts to maintain a distance from his subjects, and avoids making connections between the female star and Berlusconi, but the description of his voyeuristic search for Deborah as a certain 'type' speaks to a desire to perpetuate the connection of female beauty on display with a touch of 'incoscienza':

Deborah l'ho cercata la notte facendo zapping - e casting - tra le telefoniste erotiche delle television regionali. [...] Ore e ore di visioni e di ascolti finché una notte è apparsa Deborah (in arte Laura), con quel suo fare inadeguato e un po' maldestro e una malinconia selvatica dentro occhi ancora privi di maschera... ${ }^{73}$

In all the cases discussed here, the visual traditions associated with 'donne di spettacolo' and the language used to talk about them makes the documentary film a treacherous form of media for women's representation, particularly when it fails to interrogate fully the departure point of the hypervisibility of their bodies in the Italian media as an anonymous, fragmented, possibly stupid, and certainly speechless, mass.

\section{Conclusion}

The picture that emerges from this preliminary review of oppositional responses to 'velinismo' is one in which verbal and visual practices raise consciousness about a problem: sexism in Italian culture, particularly television. However they also risk reinforcing certain long-standing stereotypes about the 'velina', and a whole category of 'other women', who wear too much make-up, have cosmetic surgery, and sell their bodies in one way or another. This divide is not one that the discourse seems able 
to bridge, because its elite voices are too homogenous. Where are the voices of the 'veline' in this debate (other than in the right-wing press)? ${ }^{74}$ Moreover, where are the voices of the mass female audiences, presumed in all of this discourse to be a passive sponge for the 'evil' influence of Italian television? ${ }^{75}$ In the case of the cinema, Catherine O'Rawe has argued that there is a gendered and generational connotation to the tendency of 'Italian intellectuals of the left' to 'view themselves as separate from this national audience': 'in particular, in Italy the young female audience is a source of special anxiety in this regard' ${ }^{76}$ The moral panic that the television somehow reflects a degraded Italian reality is a clear instance of 'the reflection fallacy' theorized in media studies as 'a fundamentally flawed notion: that commercial media simply hold up a mirror to a social world and publish or broadcast what they see there'. ${ }^{77}$ It is also a symptom of the tendency towards 'incredulous perplexity' described by Albertazzi and Rothenberg: 'The deep social and political fragmentation of the country and the lack of political credibility of intellectuals have determined a profound detachment between the wider popular and the cultured elites, who would often look at the country and its people with incredulous perplexity'. ${ }^{8}$

Nonetheless, a broader panic about girls and 'sexualization', whilst rooted in a very specific and extreme situation in the case of Italy and its television, is currently the subject of much debate throughout the Western World. The emergent scholarly response in the UK is best expressed through the website of the research group Onscenity: Sex, Commerce, Media and Technology in Contemporary Society:

Despite extensive debate there is still very little qualitative research on girls' everyday sexual cultures and 'sexualization'. We have seen a tendency in some of the debates to either fix girls as either objectified passive victims of sexualization or as agentic savvy navigators of sexualization (usually with limited or no data with young people themselves). But we feel strongly that such binary positions do little to help us map the messy realities of how girls are living their sexualities in specific contexts. ${ }^{79}$

Not only does this comment seem to reflect usefully on the binary positions assumed by participants in the debate within Italian culture, but it also highlights the fact that a lack of empirical evidence, and a failure to listen to certain voices, does not only dog Italy. The term postfeminist is useful in this context first and foremost, because postfeminist thought might give Italian thinkers the incentive to look outside Italy for some of the solutions to their problems, and to see what they have in common with other contexts, and not simply what marks them out as (hopelessly) different. ${ }^{80}$ The

${ }^{74}$ See for example Chiara Maffioletti's interview with Swedish Filippa Lagerbäck, 'valletta' for the programme 'La 27 a ora' in 'Donna oggetto in televisione ma con ironia', Corriere della sera, 23 April 20 Ir.

75 Michela Marzano asks: 'A forza di identificarsi con le fashion dolls, si finisce con l'introiettare il ruolo che gli uomini vogliono che le donne continuino ad avere': Michela Marzano, Sii bella e stai zitta: perché l'Italia di oggi offende le donne (Milan: Mondadori, 2010), p. 67.

${ }^{76}$ Catherine O'Rawe, 'The Italian Spectator and her Critics', The Italianist, 30:2 (2010) 282-86 (p. 283 ).

77 Mary Douglas Vavrus, Postfeminist News: Political women in media culture (New York: SUNY Press, 2002), pp. $176-77$.

$7^{8}$ Albertazzi and Rothenberg, p. 9.

79 http://www.onscenity.org/sexualization/\#blogf [accessed 6 June 20II].

${ }_{80}$ Lorella Zanardo is already taking steps in this direction with an international project, which includes the United States, on the 'rimozione dei volti adulti' from the media. 
important contribution that postfeminist theory could make in this debate is to open up understanding about what is 'new, unique, and distinctive about media representations of gender at the current moment, what ma[kes] them different from straightforwardly pre-feminist or anti-feminist portrayals'. ${ }^{\text {I }}$ The role of the 'velina' in Italian culture has evolved in tandem with the growing forces of neoliberalism, and deserves analysis as a particular form of 'new sexism'.

I suspect that postfeminist theoretical approaches would also help Zanardo, and feminist writers like Michela Marzano, to bring the female body and its pleasures back into their understanding of the situation. ${ }^{82}$ Gill and other critics in the postfeminist camp, like Feona Attwood, are striving to reconcile the exploitative aspects of 'subjectification' with an awareness that, for younger women in particular, 'sexual display has developed more positive connotations in a culture in which female celebrities routinely present their bodies as objects of spectacle which indicate success, confidence, assertive female sexuality and power'. ${ }^{83}$ As Gill has explained recently, the attempt to understand the psychosocial roots of the problem is not an unqualified celebration of the 'resistant' audience, but it represents an attempt to delve into the 'affective realm', and to understand how ideology operates there, to understand 'how it is that what is "out there" gets "in here" to reconstruct our deepest yearnings and sense of self' ${ }^{84}$ In this respect one of the feminist thinkers who has been sidelined in the debate in Italy, Lea Melandri, can be reintegrated; in response to the 'velina' problem, she suggested that: 'le donne, pur emancipate, non rinunciano facilmente a quel ruolo di madri e "seduttrici" che dà loro il potere, in gran parte fantasmatico, di sentirsi necessarie, indispensabili all'altro'. ${ }^{85}$ Her comment speaks to a potential within Italy for re-engagement with the agency and the pleasures of both the female spectator and the 'velina' or prostitute figure herself, repeatedly trampled upon in these debates in much Italian oppositional discourse, and urgently demanding address. Opening up dialogue with postfeminist media studies would thereby sharpen the tools with which mainstream critics in Italy launch their attack on a culture that is profoundly and 'newly' sexist at both a structural and representational level.

\footnotetext{
${ }^{8 \mathrm{r}}$ Rosalind Gill, 'Sexism Reloaded', p. 64.

${ }^{82}$ Zanardo, p. I39; Marzano, p. I2I.

83 Gill, Gender and the Media, p. 38.

${ }^{84}$ Gill, 'Sexism Reloaded', p. 66.

${ }^{85}$ Quoted in Campani, p. 95.
} 